\title{
Hydrogeochemistry and Environmental Properties of Geothermal Fields. Case Study: Balçova, Izmir- Turkey
}

\author{
A. Cakin , G. Gokcen , A. E. Eroğlu \& A. Baba
}

To cite this article: A. Cakin , G. Gokcen , A. E. Eroğlu \& A. Baba (2012) Hydrogeochemistry and Environmental Properties of Geothermal Fields. Case Study: Balçova, Izmir-Turkey, Energy Sources, Part A: Recovery, Utilization, and Environmental Effects, 34:8, 732-745, DOI: 10.1080/15567031003681903

To link to this article: http://dx.doi.org/10.1080/15567031003681903

Published online: 12 Mar 2012.

Submit your article to this journal ¿

Џll Article views: 114

View related articles $\sqsubset$ 


\title{
Hydrogeochemistry and Environmental Properties of Geothermal Fields. Case Study: Balçova, Izmir-Turkey
}

\author{
A. CAKIN, ${ }^{1}$ G. GOKCEN, ${ }^{2}$ A. E. EROĞLU,${ }^{1}$ and A. BABA ${ }^{3}$ \\ ${ }^{1}$ Department of Chemistry, Izmir Institute of Technology, Izmir, Turkey \\ ${ }^{2}$ Department of Mechanical Engineering, Izmir Institute of Technology, \\ Izmir, Turkey \\ ${ }^{3}$ Department of Civil Engineering, Izmir Institute of Technology, Izmir, Turkey
}

\begin{abstract}
Balcova Geothermal Field hosts the largest geothermal district heating system of Turkey and a number of shallow groundwater wells that are used for irrigation of the agricultural activities. The present study aims to assess the influence of geothermal fluid on groundwater by determining the hydrogeochemical properties of the water resources. A sampling program was conducted for 10 months and samples were collected from geothermal and groundwater wells including re-injected fluid. Trace and major elements, and the types of waters were determined. The results of groundwater analysis showed that the concentrations of some toxic species, such as arsenic, boron, and fluoride, exceeded the limits of drinking water standards set by TSE, EPA, and WHO.
\end{abstract}

Keywords Balcova, geothermal, geothermal district heating, geothermal fluid, groundwater, heavy metals

\section{Introduction}

Geothermal development in the last 40-50 years has shown that it is not completely free of adverse impacts on the environment. These impacts cause an increasing concern, and to an extent may now be limiting developments. High alteration zones are observed in most geothermal fields in the world. Highly mineralized trace elements, such as arsenic (As); boron (B); cadmium ( $\mathrm{Cd}$ ); and lead $(\mathrm{Pb})$, affect water; soil; and, consequently, crops. Once heat has been extracted, geothermal fluid is either discharged into waterways or evaporation ponds, or re-injected deep into the ground (Axtmann, 1975; Ellis, 1978; Ármannsson and Kristmannsdóttir, 1992; Webster and Timperley, 1995; Hunt, 2001; Baba and Ármannsson, 2006).

Fluids from high temperature reservoirs include a range of chemical species, namely, sodium $(\mathrm{Na})$; potassium $(\mathrm{K})$; calcium $(\mathrm{Ca})$; magnesium $(\mathrm{Mg})$; strontium $(\mathrm{Sr})$; antimony $(\mathrm{Sb})$; chloride $(\mathrm{Cl})$; fluoride $(\mathrm{F})$; iodide $(\mathrm{I})$; silicate $(\mathrm{Si})$; bicarbonate $\left(\mathrm{HCO}_{3}^{-}\right)$; and, of most concern, several toxic chemicals, such as $\mathrm{B}$; As; mercury $(\mathrm{Hg})$; lithium (Li); rubidium $(\mathrm{Rb})$; hydrogen sulphide $\left(\mathrm{H}_{2} \mathrm{~S}\right)$; and ammonia $\left(\mathrm{NH}_{4}^{+}\right)$(Hunt, 2001). However, low to medium temperature geothermal fluids used in most direct-use applications generally

Address correspondence to Dr. Gulden Gokcen, Department of Mechanical Engineering, Izmir Institute of Technology, Gulbahce Koyu, Urla-Izmir, Turkey. E-mail: guldengokcen@iyte.edu.tr 
contain low levels of chemicals and the discharge of spent geothermal fluids is seldom a major problem. Most of the chemicals present as solute, will remain in solution and are re-injected.

Geothermal fluids encountered in Turkey can be classified chemically as $95 \%$ encrusting. In three of the 140 geothermal fields, which are Tuzla-Canakkale $(65,000 \mathrm{mg} / \mathrm{L})$, Cesme-Izmir (35,000 mg/L), and Seferihisar-Izmir $(22,200 \mathrm{mg} / \mathrm{L})$, the total dissolved solids (TDS) in the geothermal fluid exceed 5,000 ppm, which could cause serious environmental problems (Gemici and Filiz, 2001, Baba and Ármannsson, 2006). Geothermal wells and hot springs in Seferihisar are not presently used except for primitive spa facilities but natural discharges have currently caused some environmental problems on soil and water with its salinity and also high boron content (Baba et al., 2005).

Boron concentrations are generally high in geothermal fluids in Turkey, such as Kursunlu-Cavundur-Cankiri (63.8 mg/L), Duzce-Derdin-Sakarya (50.6 mg/L), Germencik-Aydin (69 mg/L), Kursunlu-Salihli-Manisa (65 mg/L), and Kizildere-Denizli (>20 mg/L) (Vengosh et al., 2002; Gemici and Tarcan, 2002; Baba and Ármannsson, 2006; Gokcen et al., 2008). A fraction of effluents from the Kizildere Geothermal Power Plant-Denizli is released into the Great Menderes River and endanger natural biota and crops that are sensitive to boron. Boron contamination in the river is an example of surface water contamination by geothermal fluids.

The other trace elements, namely, As, $\mathrm{Hg}, \mathrm{Cd}$, copper $(\mathrm{Cu})$, cromium $(\mathrm{Cr}), \mathrm{Pb}$, and zinc $(\mathrm{Zn})$, were not a concern until the beginning of the 1990s in Turkey. However, with the increasing awareness of environmental issues, these elements have also been taken into account since then. Arsenic concentrations on western Turkey were encountered in a range of $0.13-0.28 \mathrm{mg} / \mathrm{L}$ while Cd concentrations were $0.048-0.1 \mathrm{mg} / \mathrm{L}$. Lead, Cu, and $\mathrm{Zn}$ concentrations were determined as $0.076-1,0.03-1.2$, and $0.06-1.2 \mathrm{mg} / \mathrm{L}$, respectively (Gocmez and Guzel, 1994; Kacaroglu et al., 1994; Corsi, 1995; Giese, 1997; Gemici and Filiz, 2001; Celik and Sabah, 2002; Dogdu and Bayarı, 2002; Tarcan and Gemici, 2003; Gokcen et al., 2008). Arsenic, $\mathrm{Cd}$, and $\mathrm{Pb}$ concentrations exceeded the limits set by Turkish Standards Institution (TS266, 2005), United States Environmental Protection Agency (EPA, 2003), and World Health Organisation (WHO, 2006) for drinking water while $\mathrm{Cu}$ and $\mathrm{Zn}$ were below the limits.

Geological (Konuk, 1977; Erdoğan, 1990; Ongur, 2001), tectonic (Kaya, 1999; Yilmaz et al., 2000), hydrogeological (Yilmazer, 1989; Serpen, 2004; Aksoy et al., 2008), and reservoir properties (Serpen and Mihcakan, 1999; Serpen and Kayan, 2001; Satman et al., 2002) of Balcova Geothermal Field, Izmir-Turkey were studied widely, but very few studies have been conducted about the environmental properties of the field (Cakın, 2003; Aksoy et al., 2009). Since the surroundings of the field are a fertile agricultural area, groundwater is used densely for irrigation. This study aims to determine the hydrogeochemical properties of water resources of Balcova Geothermal Field and to evaluate effects of geothermal fluid on groundwater.

\section{Study Area}

Balçova Geothermal Field (BGF) or so-called Agamemnon Spas have been an attractive place for settlers over the ages. Agamemnon Spas were known in antiquity for the therapeutic qualities of the water. At the present time, Balcova is still famous for its spa complex $\left(1.4 \mathrm{MW}_{\mathrm{t}}\right)(1989)$, olympic indoor swimming pool (1.9 $\left.\mathrm{MW}_{\mathrm{t}}\right)(1987)$, and thermal hotels. BGF is located at $7 \mathrm{~km}$ west of Izmir province and covers a total area of approximately $3.5 \mathrm{~km}^{2}$ (Figure 1a). 


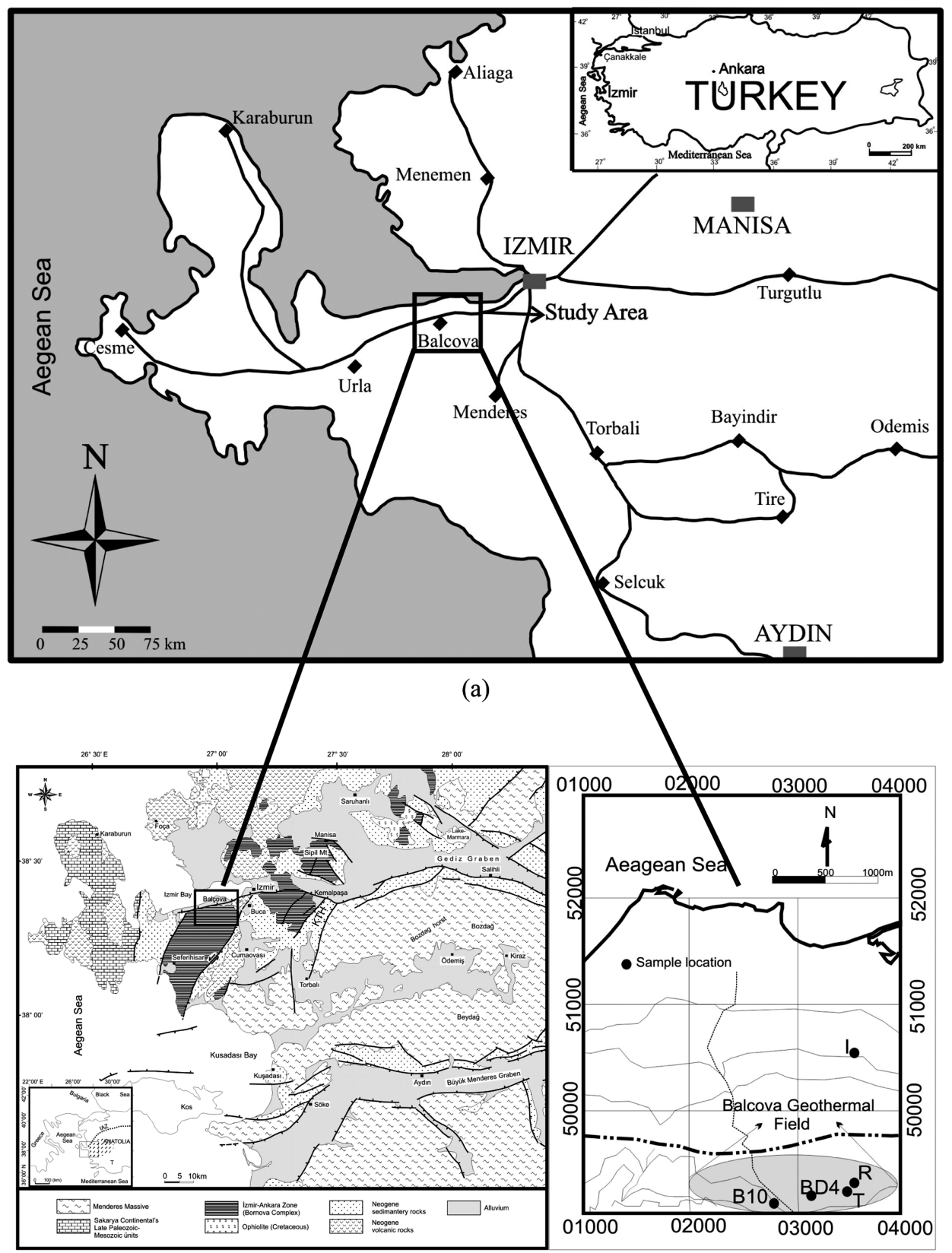

(b)

(c)

Figure 1. (a) Location map. (b) Geological map (modified after Yilmaz et al., 2000). (c) Sampling points of study area. 
The reconnaissance and exploration studies were initiated in the field in 1963 and Turkey's first downhole heat exchanger was applied in 1982. Then Balcova Geothermal District Heating System was commissioned in 1996. As of April 2009, the field houses the largest geothermal district heating system of Turkey $\left(75 \mathrm{MW}_{\mathrm{t}}\right)$, a modern spa complex with a total capacity of 1,000 persons/day, and approximately 10 ha greenhouse heating with 15 production and 2 re-injection wells. Besides geothermal production and reinjection wells, the field contains numerous groundwater wells that are used for irrigation of the agricultural fields and greenhouses.

\section{Geological and Hydrogeological Properties of Balcova Geothermal Field}

The flysch-type metasediments, named the Bornova melange by Erdoğan (1990), of Campanian to Danian in age (Konuk, 1977; Ozer and Irtem, 1982) crop out around the study area (Figure 1b). These metasediments are subdivided into a sequence of weakly deformed brown and grey phyllites, and a pack of highly deformed dark sericitic meta-pelites. These two subunits comprise turbidities, characterized by repeated graded bedding in the centimeters scale. Gradual transitions from clastic to calcareous shales occur in either group, though more frequently in the phyllites. The carbonate content was locally high enough to form incompetent calcareous shales and locally competent lenses of massive limestones. Intercalations of greywackes and polygenetic debris flows conglomerates indicate continued unsteady conditions of sedimentation, as do the sizeable but rootless olistoliths of up to $50 \mathrm{~m}$ thick, platform-type massive limestones (Baba and Gungor, 2002). Campanian- to Danian-aged rock sequences that overlie the basement units and are unconformably overlain by Quaternary alluvium, which is most probably derived from sheetwash deposits, fan deposits, and coastal wind blown sediments, have been observed along the flat terrain that extends between the foothills of the mountains and the shoreline. It is mostly fine-grained (silt and sand) and covers the major agricultural fields of the study area.

The Balcova geothermal system is a fracture zone system in which hot water ascends over an area of about $2 \mathrm{~km}$ along a major fracture zone associated with the Agamemnon Fault (Serpen, 2004). In the field, geothermal processes are extremely vigorous and hot waters close to boiling temperature can be observed at the surface (Magri et al., 2009). The hot water discharges via two concealed horizontal flows, one in the unconfined alluvium aquifer, which is extremely permeable and transmits significant amounts of water, and another deeper one in more permeable, unclear layers in the flysch formation between 400 and $700 \mathrm{~m}$ depth (Serpen, 2004). The thickness of the unconfined aquifer ranges from 50 to $150 \mathrm{~m}$. The cold water of this aquifer is pumped via wells that are about $30 \mathrm{~m}$ deep. The groundwater table in the shallow surficial aquifer is between 5 and $20 \mathrm{~m}$ from the ground surface (Aksoy et al., 2009).

\section{Materials and Method}

A sampling program was designed to collect geothermal and groundwater samples monthly between September 2002 and June 2003 for 10 months. In respect to the sampling program, two production wells (BD4 and B10), the re-injection line (R) downstream of the main heat exchanger exit, and two groundwater wells ( $T$ and $\mathrm{I}$ ) were selected. The location of the sampling points is shown in Figure 1c. The B10 well was chosen as a representative production well since it is operated all year round. Furthermore, the B10 
well has a high $\mathrm{Mg}$ content, which is a property of surface water, and shows a possible mixing of geothermal fluid with groundwater. The BD4 well, which was the highest temperature well in the field, was operated only during the heating season. The reinjection line $(\mathrm{R})$ serves to the re-injection wells and it represents the waste fluid rejected to the underground where possible mixing with groundwater occurs. Groundwater wells $\mathrm{T}$ and I were chosen because of their location on south and north ends of the field. Furthermore, well I is used for irrigation.

The samples were collected as two sets from each sampling point, one for determination of anions and another for cations, and stored in pre-cleaned polyethylene bottles for laboratory analysis, whereas temperature and $\mathrm{pH}$ were determined in-situ. Following sample collection, electrical conductivity (EC) was measured and chemical analyses were performed as quickly as possible in the laboratory. If immediate analysis was not possible, samples were stored at $4^{\circ} \mathrm{C}$ in a dark room. The remaining major chemical constituents were determined using standard methods described in AWWA (1995). Bicarbonate $\left(\mathrm{HCO}_{3}^{-}\right)$and chloride $\left(\mathrm{Cl}^{-}\right)$ions were determined with neutralization and precipitation titrations, respectively. A gravimetric method was applied in the determination of sulphate $\left(\mathrm{SO}_{4}^{2-}\right.$ ) and total dissolved solid (TDS). Fluoride ion was determined with an ion-selective electrode. Major cations $(\mathrm{K}, \mathrm{Na}, \mathrm{Ca}, \mathrm{Mg}$ ) and $\mathrm{Cu}, \mathrm{Cr}, \mathrm{Cd}, \mathrm{Pb}, \mathrm{Zn}$, $\mathrm{B}$, and $\mathrm{Si}$ were determined by inductively coupled plasma atomic emission spectrometry at the laboratories of the Chemistry Department and Center for Environmental Research at Izmir Institute of Technology, Izmir-Turkey.

\section{Results and Discussion}

\section{Physical Properties of Water Resources}

During the sampling period, minimum and maximum surface temperatures of groundwater were measured as $14^{\circ} \mathrm{C}$ at well $\mathrm{T}$ and $41^{\circ} \mathrm{C}$ at well $\mathrm{I}$, respectively. The high surface temperature of groundwater well I points out the geothermal fluid interaction. The wellhead temperature of geothermal wells BD4 and B10 changed between $95-138^{\circ} \mathrm{C}$ and $80-98^{\circ} \mathrm{C}$, respectively. Sample pH, EC, and TDS values were plotted in Figure 2. As can be seen from Figure 2, EC values of groundwater well I reflect the geothermal fluid characteristic and are approximately three times higher than groundwater well $\mathrm{T}$. All $\mathrm{pH}$ and EC values of the samples were within the limits of TS266, EPA, and WHO standards. TDS values of geothermal wells can range from a few hundred to more than $300,000 \mathrm{mg} / \mathrm{L}$. The concentration of TDS in the selected sampling points exceeded the limits of standards except well $\mathrm{T}$.

\section{Chemical Properties of Water Resources}

Major Anions and Cations. Major anions $\left(\mathrm{HCO}_{3}^{-}, \mathrm{SO}_{4}^{2-}, \mathrm{Cl}^{-}, \mathrm{F}^{-}\right)$and cations $\left(\mathrm{Ca}^{2+}\right.$, $\mathrm{Mg}^{2+}, \mathrm{K}^{+}, \mathrm{Na}^{+}, \mathrm{NH}_{4}^{+}$) in the samples were determined. Bicarbonate concentrations of the samples changed gradually in all samples depending on the precipitation. During the alkalinity analysis, the color of the geothermal fluid samples did not change with the addition of the phenolphthalein, which showed the absence of carbonate. On the other hand, $\mathrm{HCO}_{3}^{-}$alkalinity existed in each sample. Ammonia concentrations of all wells including well $\mathrm{T}$ changed considerably during the sampling period, which can be explained by the recharge of cold groundwater to geothermal fluid (Figure 3a). Except for a few samples, all wells had $\mathrm{NH}_{4}^{+}$concentrations above the permissible limits according to drinking water 


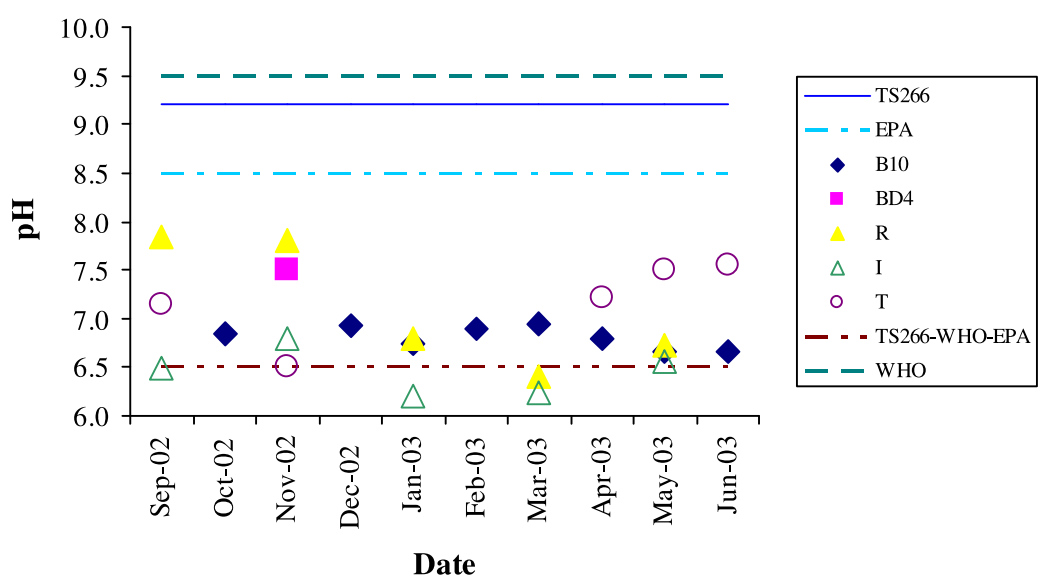

(a)

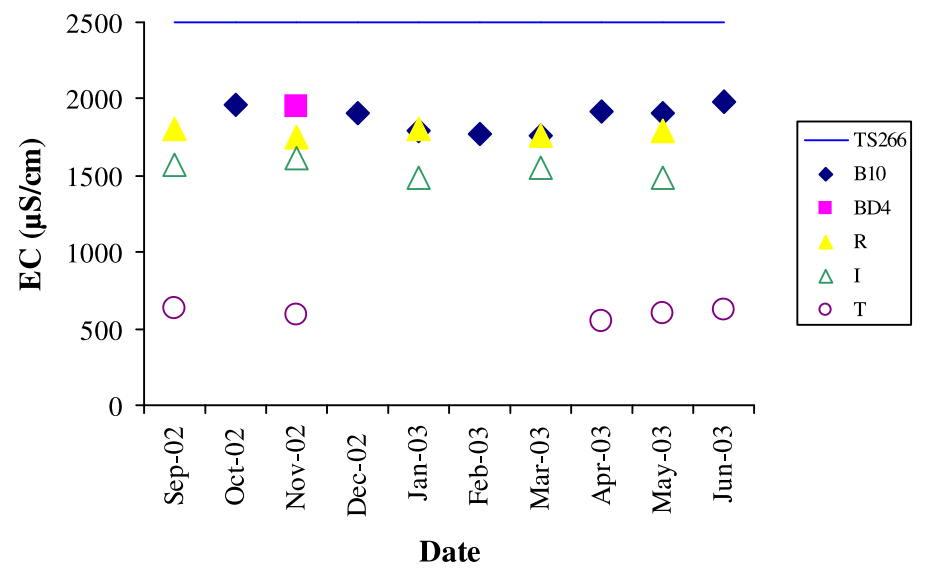

(b)

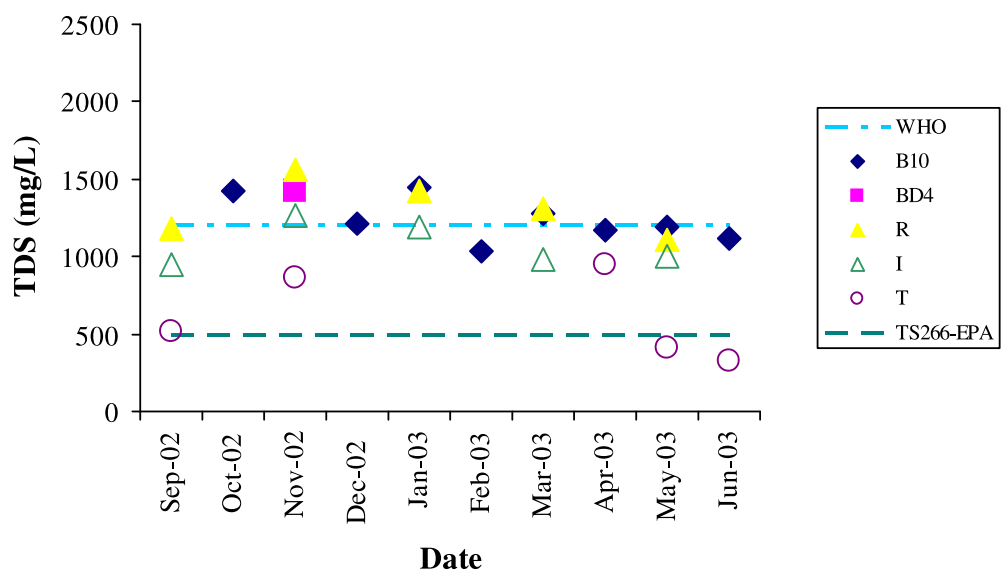

(c)

Figure 2. Distribution of physical properties of water resources in Balcova Geothermal Field: (a) $\mathrm{pH}$, (b) EC, and (c) TDS. (color figure available online) 


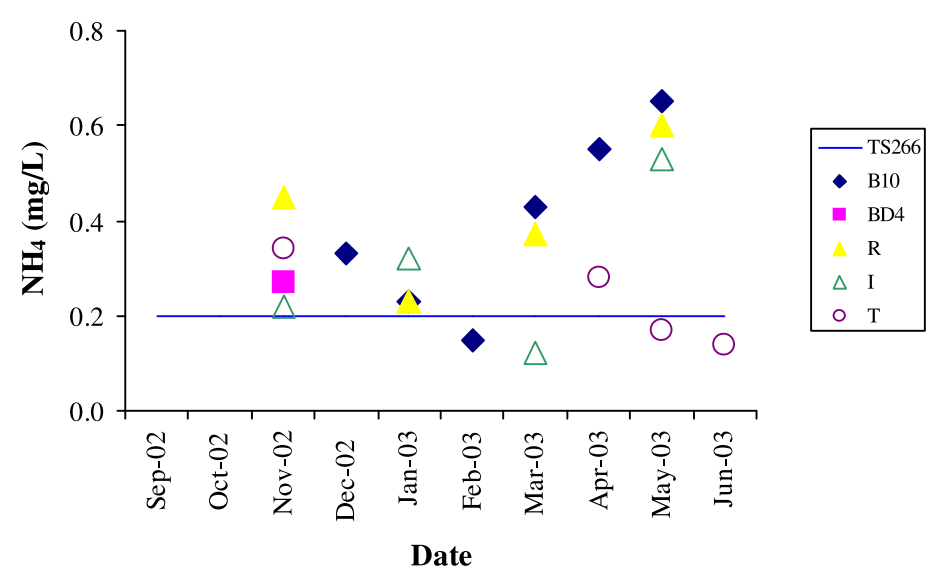

(a)

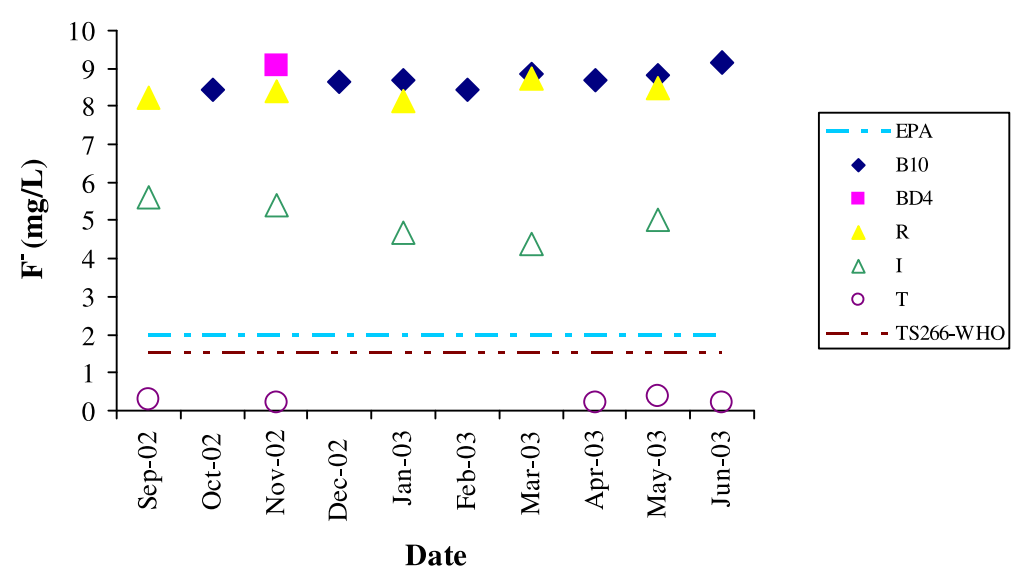

(b)

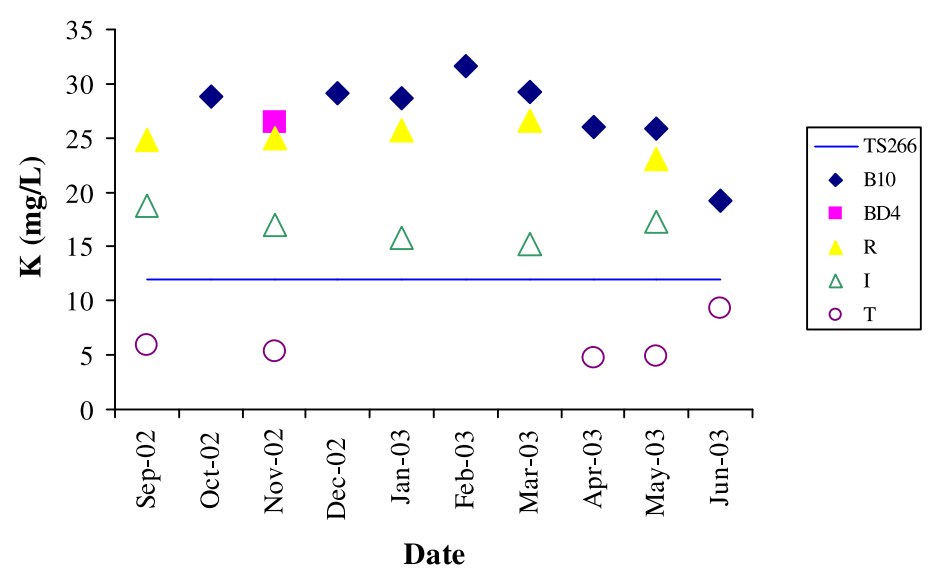

(c)

Figure 3. Concentration of major cations and anions of water resources in Balcova Geothermal Field: (a) $\mathrm{NH}_{4}$, (b) $\mathrm{F}^{-}$, and (c) $\mathrm{K}$. (color figure available online) 
standards. Well $\mathrm{T}$ had $\mathrm{NH}_{4}^{+}$concentrations under the permissible limits only in summer time. According to TS266 and WHO, the permissible limit for $\mathrm{F}^{-}$is $1.5 \mathrm{mg} / \mathrm{L}$. Groundwater wells I and $\mathrm{T}$ differ strongly in terms of $\mathrm{F}^{-}$concentration. While well $\mathrm{T}$ was under the limits of TS266, EPA, and WHO standards, well I exceeded the limits throughout the sampling period, which indicates the geothermal influence (Figure 3b). The concentration of K should not exceed $12 \mathrm{mg} / \mathrm{L}$ according to TS266. At well T, its concentrations were under the permissible limits while other samples exceeded the limits (Figure 3c).

Geothermal wells in the field are operated in full capacity during the winter season but only one or two wells are active in the summer for domestic hot water supply. An increase in the $\mathrm{Cl}^{-}$concentration in well I was obvious in winter time, which shows the sign of geothermal fluid interaction compared to well $\mathrm{T}$. Calcium concentrations in the geothermal fluids are controlled by minerals [calcium carbonate $\left(\mathrm{CaCO}_{3}\right)$, calcium sulfate $\left(\mathrm{CaSO}_{4}\right)$, etc.]. The permissible limit for $\mathrm{Mg}$ is $50 \mathrm{mg} / \mathrm{L}$ and $\mathrm{Mg}$ concentrations in all wells were within the limits. The concentrations were constant in B10 and R. Magnesium is a sign of surface waters. Well $\mathrm{T}$ has the highest $\mathrm{Mg}$ concentration while well I gave a concentration closer to geothermal fluid. The land $\mathrm{SO}_{4}^{2-}, \mathrm{Ca} \mathrm{Cl}^{-}$, and $\mathrm{Mg}$ concentrations of all samples $\mathrm{Na}$ concentrations of only well $\mathrm{T}$ and I were under the permissible limits according to drinking water standards.

\section{Heavy Metals}

Studies conducted in western Turkey have shown that As and B concentrations in geothermal fluids are extremely high and this was the condition in Balcova Geothermal Field as well. These two toxic species originated from the result of water-rock interaction and explains the higher concentrations in geothermal fluids than groundwater. These relatively high concentrations affect groundwater and, consequently, agricultural products by irrigation. The concentration of As in geothermal and groundwater samples exceeded TS266, EPA, and WHO standards during the sampling period (Figure 4a). Geothermal fluids have higher B concentrations than groundwater. While groundwater well $\mathrm{T}$ was around the upper limits of TS266, well I showed much higher B concentrations close to geothermal wells (Figure 4b), which indicates geothermal fluid interaction. Manganese (Mn) concentrations were almost constant at all wells except well I, where a decrease in winter months was observed. Well I exceeded the limits of drinking water standards (Figure 4c). While Al concentrations of groundwater wells exceeded the limits of the standards as shown in Figure 4d, Cr concentrations (Figure 4e) were above the permissible limits of TS266 and the WHO.

\section{Hydrogeochemical Properties of Water Resources}

Chemical characteristics of water compositions, on the basis of major ion concentrations, were evaluated on the Piper and Schoeller diagram (Figures 5a-5k). When the concentrations of the elements are evaluated, generally it can readily be seen that three types of water exist in BGF. The first type of water is relatively rich in $\mathrm{Na}-\mathrm{Cl}-\mathrm{HCO}_{3}$ (sodiumchloride-bicarbonate type), which can be seen in production wells and reinjection lines (geothermal water-BD4-B10-R). The second type is relatively rich in $\mathrm{Na}-\mathrm{HCO}_{3}$ (sodiumbicarbonate type), which can be seen in groundwater well I. Finally, the third type of water is relatively rich in $\mathrm{Ca}-\mathrm{Mg}-\mathrm{HCO}_{3}$ (calcium-magnesium-bicarbonate type), which can be seen in groundwater well T. Hydrogeochemical diagrams also show that well I have been affected by geothermal fluid. The composition of groundwater is normally $\mathrm{Ca}-\mathrm{Mg}-\mathrm{HCO}_{3}$ in this region, while the hydrogeochemical properties of well $\mathrm{I}$ is $\mathrm{Na}-\mathrm{HCO}_{3}$. 


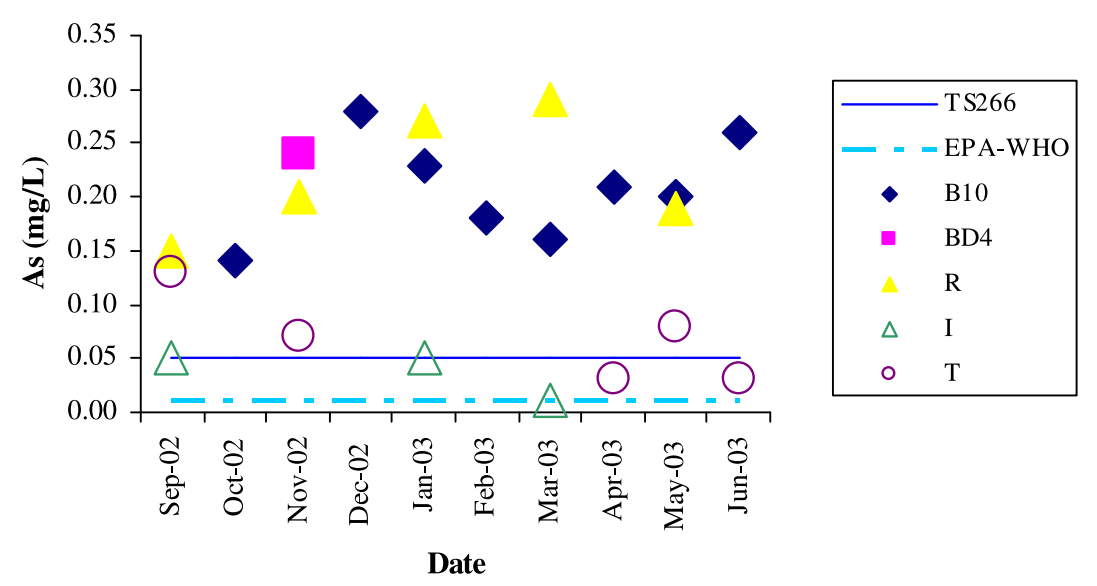

(a)

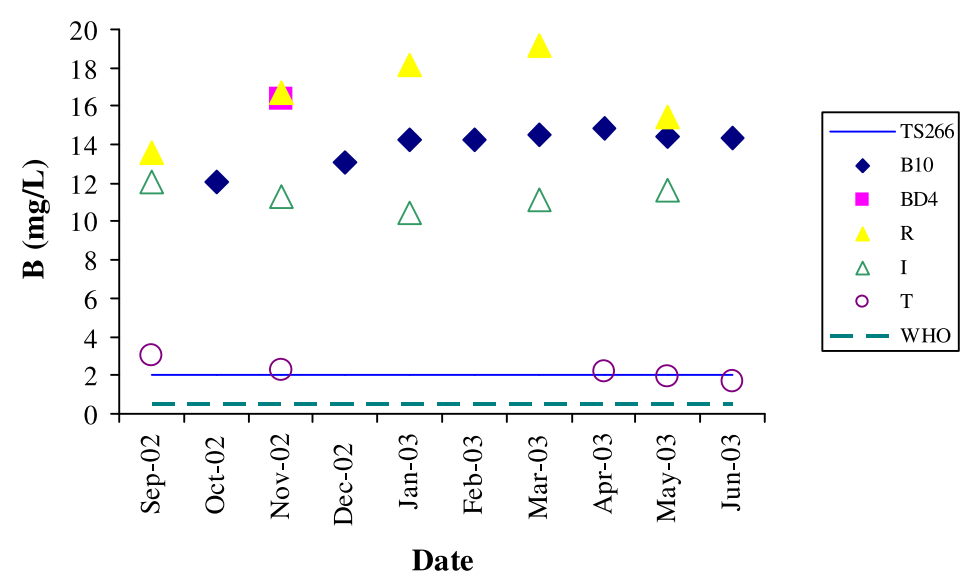

(b)

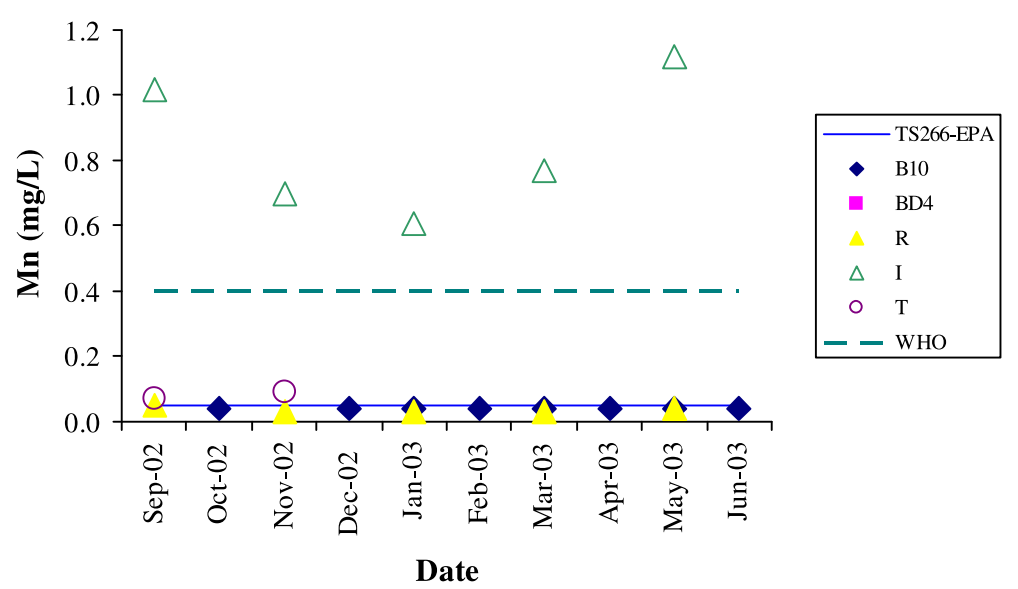

(c)

Figure 4. Concentration of heavy metals in water resources in Balcova Geothermal Field: (a) As and (b) B. (color figure available online) (continued) 


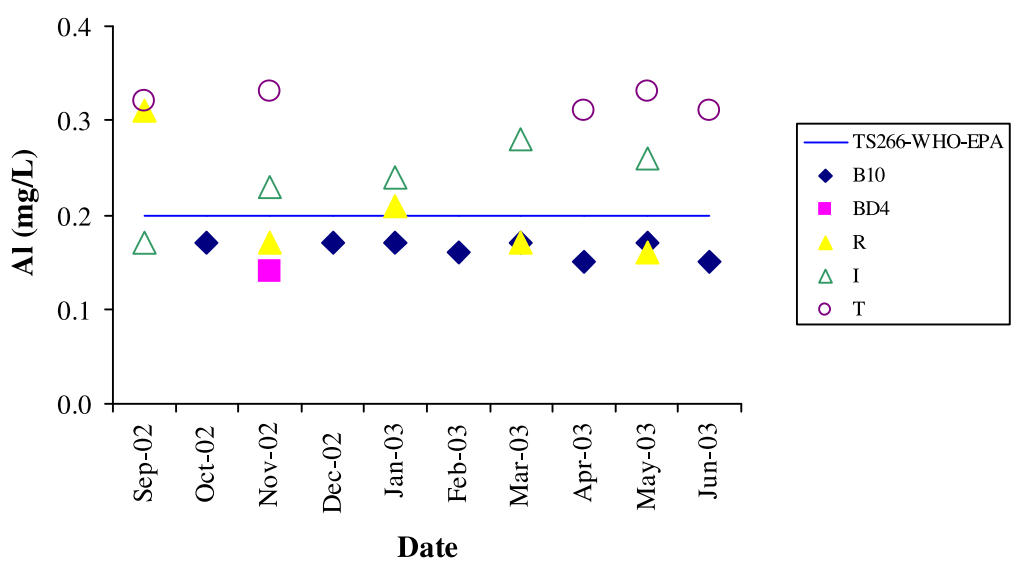

(d)

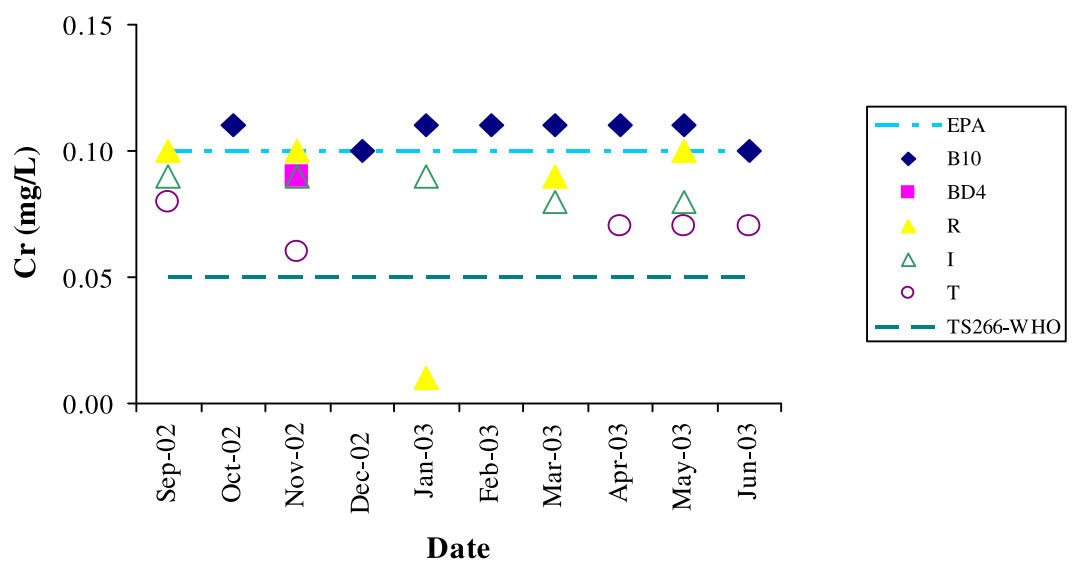

(e)

Figure 4. (Continued).

\section{Conclusions}

Geothermal fluids generally carry a variety of toxic chemicals, such as $\mathrm{As}, \mathrm{Pb}, \mathrm{Zn}$, and $\mathrm{B}$, together with significant amounts of carbonates, $\mathrm{Si}, \mathrm{SO}_{4}^{2-}$, and $\mathrm{Cl}^{-}$. Discharge of waste waters is also a potential source of chemical pollution. Spent geothermal fluids with high concentrations of chemicals should be treated or re-injected into the reservoir, or both. The results of this study show that the shallow aquifer has been affected by geothermal fluid. For example, the concentration of some ions, such as fluoride and chloride, and some heavy metals and metalloids, such as arsenic and boron, are very high in cold groundwater, which is abstracted at the shallow groundwater aquifer. This aquifer has been used for agriculture activity densely. It is important to minimize the effect of geothermal fluid to shallow aquifers. Therefore, re-injection of thermal waters to the reservoir is the best way to dispose of the geothermal waste water and prevent contamination problems. On the contrary, groundwater may be contaminated if the reinjection wells fail, which may 


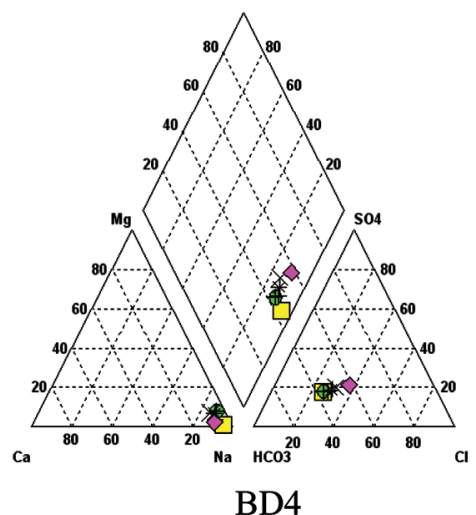

(a)
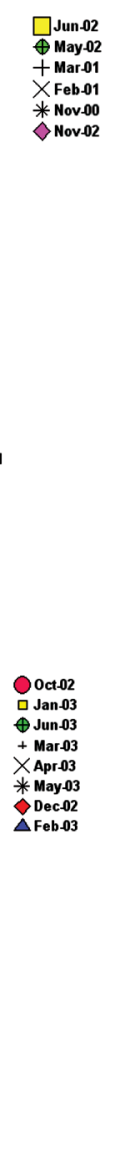

$\mathrm{B} 10$

(c)

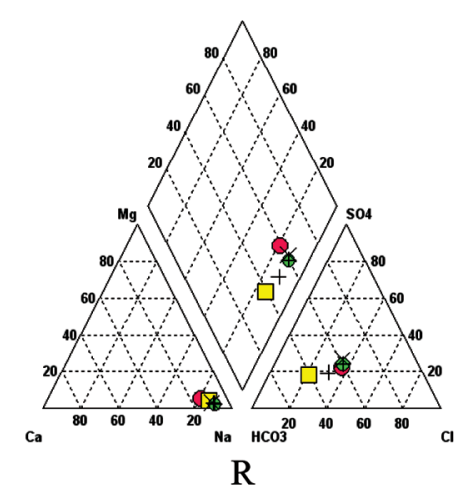

(e)

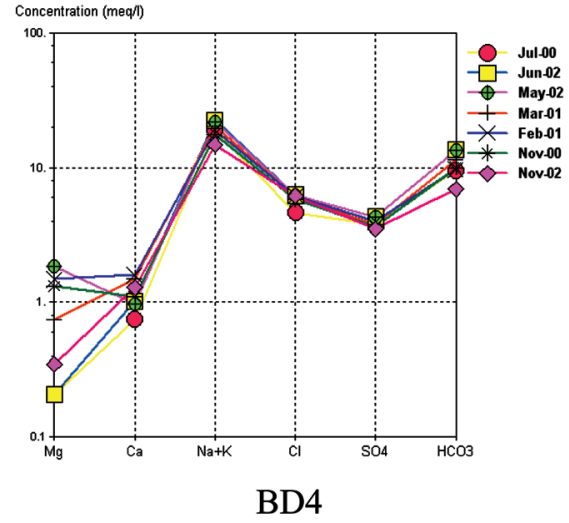

(b)

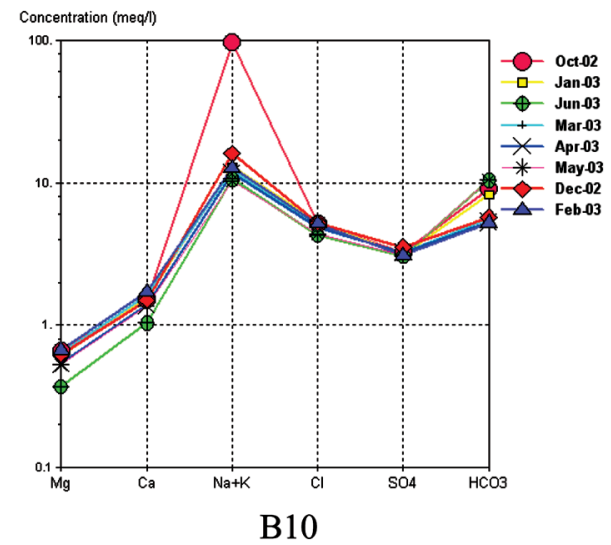

(d)

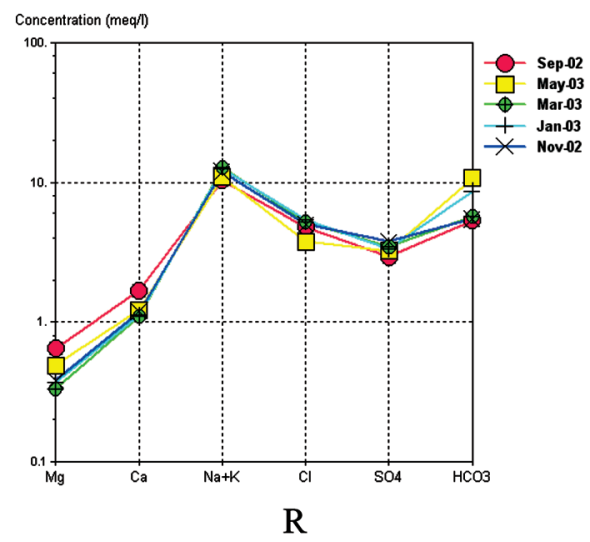

(f)

Figure 5. Piper and Schoeller diagram showing the major ionic composition of the sampled geothermal water (BD4, B10), the reinjection water (R), and groundwater (I and T). (color figure available online) (continued) 


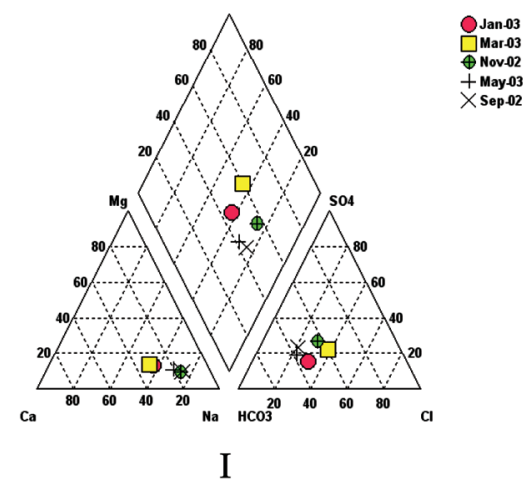

(g)

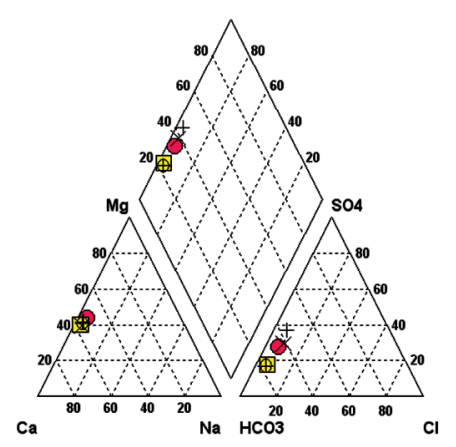

T

(i)

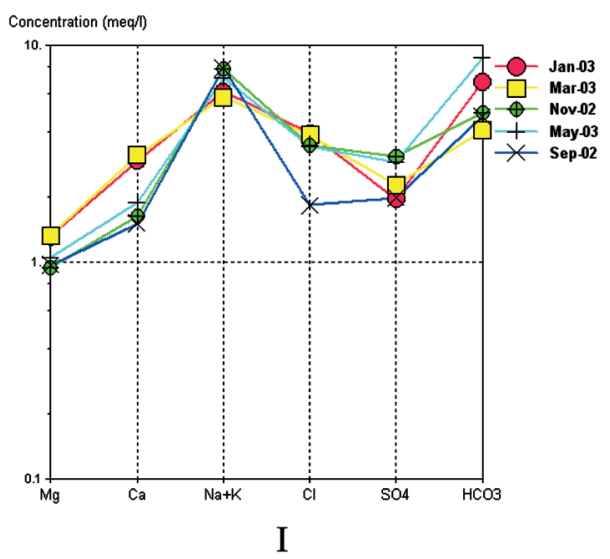

(h)

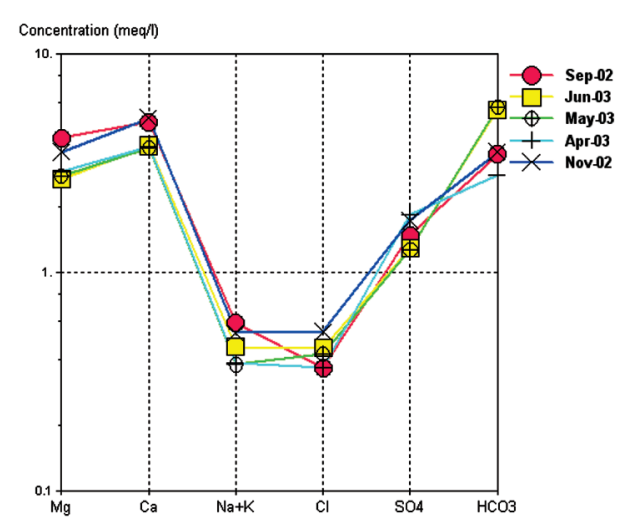

$\mathrm{T}$

Figure 5. (Continued).

allow the fluid to pass into shallow aquifers. However, this can be eliminated by careful design, attention to quality control during drilling and construction, and monitoring during operation. Since the shallow wells in the field exhibit geothermal characteristics, drilling of the cold water wells without permission should be prevented. The results of the analysis show that all geothermal waters in the investigated area were found to be inappropriate for drinking purposes according to the standards. Furthermore, geothermal fluid is unsuitable to be used for irrigation because of high boron concentrations. Since the geothermal fluid is not suitable for drinking and irrigation purposes, the adverse effects should be declared to the public.

\section{Acknowledgments}

The authors would like to thank Izmir Geothermal Inc., the operator of Balcova Geothermal Field, for allowing them to work on the field. Special thanks to the Environmental 
Research Center and Chemistry Department of Izmir Institute of Technology for the chemical analyses.

\section{References}

Aksoy, N., Serpen, U., and Filiz, Ş. 2008. Management of the Balcova-Narlidere geothermal reservoir, Turkey. Geothermics 37:444-466.

Aksoy, N., Şimşek, C., and Gunduz, O. 2009. Groundwater contamination mechanism in a geothermal field: A case study of Balcova, Turkey. J. Contam. Hydrol. 103:13-28.

American Waste Water Association (AWWA). 1995. Chemical oxygen demand, argentometric method. In: Standard Methods for the Examination of Water and Wastewater, 4th Edition, Issue 49. Washington: American Public Health Association, pp. 5-12.

Ármannsson, H., and Kristmannsdóttir, H. 1992. Geothermal environmental impact. Geothermics $21: 869-880$.

Axtmann, C. R. 1975. Environmental impact of a geothermal power plant. Science 187:795-803.

Baba, A., and Ármannsson, H. 2006. Environmental impact of the utilization of a geothermal area in Turkey. Energy Sources 1:267-278.

Baba, A., and Gungor, T. 2002. Influence of gold mine on groundwater quality (Efemçukuru, Izmir, Turkey). Environ. Geol 41:621-627.

Baba, A., Özcan, H., and Deniz, O. 2005. Environmental impact by spill of geothermal fluids at the geothermal field of Tuzla, Canakkale-Turkey. Proceedings World Geothermal Congress [CD-ROM], Antalya, Turkey, April 24-29, pp. 1-8.

Cakın, A. 2003. Environmental effects of geothermal application. Case study: Balcova Geothermal Field. Ms. Thesis, Izmir Institute of Technology, Izmir, Turkey, 97 pp.

Celik, Y. M., and Sabah, E. 2002. The geological and technical characterization of Omer-Gecek geothermal area and the environmental impact assessment of geothermal heating system in Afyon, Turkey. Environ. Geol. 41:942-953.

Corsi, R. 1995. Environmental protection aspects related to injection. Pre-congress Course of World Geothermal Congress, International Institute for Geothermal Research, International School of Geothermics, Pisa, Italy, May 18-20, pp. 147-171.

Dogdu, M. S., and Bayarı, C. S. 2002. Pollution of geothermal origin in the Akarçay basin (Afyon, Turkey): 1. Water and sediment pollution in the Akarçay stream. Bull. Earth Sci. 25:21-33.

Ellis, J. A. 1978. Environmental impact of geothermal development. United Nations Environmental Programme (UNEP).

Environmental Protection Agency (EPA). 2003. List of drinking water contaminants and MCLs, National Primary Drinking Water Regulations. U.S. Environmental Protection Agency. Available from http://www.epa.gov/safewater

Erdoğan, B. 1990. Tectonic relations between Izmir-Ankara zone and Karaburun belt. Mineral Res. Expl. Bull. Turkey 110:1-15.

Gemici, U., and Filiz, S. 2001. Hydrochemistry of the Cesme geothermal area in western Turkey. J. Volcanol. Geotherm. Res. 110:171-187.

Gemici, U., and Tarcan, G. 2002. Distribution of B in thermal waters of western Anatolia, Turkey and examples of their environmental impacts. Environ. Geol. 43:87-98.

Giese, L. B. 1997. Geotechnische und Umweltgeologische Aspekte bei der Förderung und Reinjection von Thermalfluiden zur Nutzung Geothermischer Energie am Beispiel des Gothermalfeldes Kizildere und des Umfeldes, W-Anatolien/Turkei [Geotechnical and enviro-geological aspects in the production and reinjection of the thermal fluids for geothermal energy utilization. Case Study: Kizildere geothermal field and its surroundings in Western Anatolia/Turkey]. Ph.D. Thesis, FU Berlin, Germany, 201 pp. (in German).

Gocmez, G., and Guzel, A. 1994. Ziga-Yaprakhisar-Ilisu- Ihlara- Belisirma (Aksaray) Sicak ve Mineralli Su Kaynaklarının Korunma Alanları ve Kirlenebilirliği [Contamination and protection area of Ziga-Yaprakhisar-Ilisu-Ihlara-Belisirma (Aksaray) hot and mineral resources]. Jeotermal Uygulamalar Sempozyumu '94, Denizli, Turkey, September 27-30, pp. 225-234 (in Turkish). 
Gokcen, G., Cakan Sofuoglu, A., Yenidunya, A. F., Yasa, I., Eroğlu, A. E., Ozdemir, S., and Elci, S. 2008. Evaluation of geothermal development in Turkey from the clean energy point of view. Case studies: Balcova district heating system-Izmir and Kizildere geothermal power plant-Denizli, Tubitak. Project No: 104M301 (in Turkish), Ankara, Turkey: TUBITAK.

Hunt, M. T. 2001. Five lectures on environmental effects on geothermal utilization. Reykjavik, Iceland: UNU Geothermal Training Programme 2000-Report 1, 109 pp.

Kacaroglu, F., Nacitarhan, V., Degirmenci, M., Hizmetli, S., Elden, H., and Goker, I. 1994. SivasSicakcermik Termal Suyunun Hidrojeolojisi ve Gonartrozlu Olgularda Terapotik Olarak Fizik Tedavi Yontemleri ile Karsilastirilmasi [Hydrogeology of Sivas-Sicakermik thermal water and comparison of physical therapy methods for Gonartroz]. Jeotermal Uygulamalar Sempozyumu '94, Denizli, Turkey, September 27-30, pp. 281-295 (in Turkish).

Kaya, O. 1999. Fault composition of western Anatolia: Assessment with regards to petroleum and geothermal potential. Symposium on the Industrial Raw Materials of Western Anatolia (BAKSEM), Izmir, Turkey, March 8-14 (in Turkish).

Konuk, T. 1977. Bornova Filisinin Yasi Hakkinda [About Bornova flysch]. E.U. Fen. Fak. Dergisi Seri B:65-74 (in Turkish).

Magri, F., Pekdeger, A., Gemici, U., and Akar, T. 2009. Numerical simulations of deep geothermal groundwater flow in the Seferihisar-Balçova geothermal system, Turkey. Geophysical Research Abstracts 11:EGU2009-1187.

Ongur, T. 2001. Geology of Izmir Agamemnon hot springs-Balcova geothermal area and new conceptual geological model. Izmir, Turkey: Balcova Geothermal Ltd., 24 pp. (in Turkish).

Ozer, S., and Irtem, O. 1982. Işıklar-Altındağ (Bornova-Izmir) Alanı Üst Kretase Kireçtaşlarının Jeolojik Konumu, Stratigrafisi ve Fasiyes Özellikleri [Geological setting, stratigraphy and fades characteristics of the Upper Cretaceous limestones in the Işıldar-Altındağ (Bornova-Izmir)]. Türkiye Jeoloji Kur. Bült. 24:42-47.

Satman, A., Onur, M., and Serpen, U. 2002. Production performance project of Balcova-Narlidere Geothermal Field. Project Report. Istanbul, Turkey: Balcova Geothermal Inc., Department of Petroleum and Natural Gas, Istanbul Technical University, 512 pp. (in Turkish).

Serpen, U. 2004. Hydrogeological investigations on Balcova geothermal system in Turkey. Geothermics 33:309-335.

Serpen, U., and Kayan, I. 2001. Hydraulic balance of Balcova Geothermal Field. Proceedings of 13th International Petroleum Congress and Exhibition, Ankara, Turkey, June 4-6.

Serpen, U., and Mihcakan, M. 1999. Heat flow and related geothermal potential of Turkey. Geotherm. Resour. Council Trans. 23:485-490.

Tarcan, G., and Gemici, U. 2003. Water geochemistry of the Seferihisar geothermal area, Izmir, Turkey. J. Volcanol. Geotherm. Res. 126:225-242.

TS266. 2005. Drinking Water Standard. Turkish Standard No.: TS266, Ankara, Turkey.

Vengosh, A., Helvaci, C., and Karamanderesi, H. I. 2002. Geochemical constraints for the origin of thermal waters from western Turkey. Appl. Geochem. 17:63-183.

Webster, J. G., and Timperley, M. H. 1995. Biological impacts of geothermal development. Course on Environmental Aspects of Geothermal Development, Brown, K. L. (Convener), Pre-Congress Courses, Pisa, Italy, May 18-20, pp. 97-117.

WHO. 2006. Guidelines for Drinking Water Quality: First Addendum to Third Edition, Recommendations, Geneva, Switzerland: World Health Organisation.

Yilmaz, Y., Genç, S. C., Güner, F., Bozcu, M., Yılmaz, K., and Koracık, Z. 2000. When did the western Anatolia Grabens begin to develop. In: Tectonics and Magmatism in Turkey and the Surrounding Area, Bozkurt, E., Winchester, S. A., and Piper, J. D. A. (Eds.). London: Geological Society, Special Pub.: vol. 173, pp. 353-384.

Yilmazer, S. 1989. Geochemical features of Balcova hot springs and geothermal energy possibilities for the area. $\mathrm{PhD}$. Dissertation Thesis, Isparta, Akdeniz University, Graduate School, Isparta, Turkey (in Turkish). 